\title{
Unprepared and Misinformed Parents of Children with Sickle Cell Disease: Time to Rethink Awareness Campaigns
}

\author{
Seyi Aderotoye-Oni ${ }^{1}$, Ijeoma N. Diaku-Akinwumi ${ }^{2}$, Adeyinka Adeniran ${ }^{3}$, Bode Falase ${ }^{4}$ \\ 1. Internal Medicine, University of Pittsburgh Medical Center Pinnacle, Harrisburg, USA 2. Paediatrics, Lagos State \\ University Teaching Hospital, Lagos, NGA 3. Epidemiology and Public Health, Lagos State University Teaching \\ Hospital, Lagos, NGA 4. Cardiothoracic Surgery, Lagos State University Teaching Hospital, Lagos, NGA
}

Corresponding author: Seyi Aderotoye-Oni, seyi.aderotoye@gmail.com

\begin{abstract}
Worldwide, sickle cell disease (SCD) poses a significant public health concern. It causes recurrent morbidity, and premature death is a distinct possibility, especially in Nigeria, which bears half the world's burden of SCD patients. Nigeria has yet to establish a newborn screening program; consequently, most affected children are diagnosed between one and three years of age when a health problem arises. Parents are unprepared to identify SCD and seek comprehensive management early enough for the best outcome. Awareness of carrier status and knowledge of SCD would ensure informed reproductive choices.
\end{abstract}

Questionnaires were employed to conduct a prospective, cross-sectional study of the occurrence of missed carrier status of one biological parent of children enrolled at the pediatric sickle cell disease clinic of a teaching hospital. The institution's ethics committee approved the study.

Of 133 respondents, $53 \%$ of the parents were unaware of being sickle cell carriers and did not expect to have children with SCD. Among families in which one or both parents proactively sought to know their genotype, $35 \%$ of all parents received incorrect genotyping results regarding the SCD risk of their offspring. The majority of incorrectly assigned hemoglobin AA results occurred in private laboratories. More than $60 \%$ of the respondents reported gaining awareness regarding SCD through antenatal care (51\%) and schools (17\%), as opposed to public awareness campaigns (8\%).

Many parents in our study population were unprepared for their children's SCD diagnosis. Awareness campaigns need to be revisited as a major potential modality to increase outreach about SCD.

Standardization and improved quality control of laboratory testing involving screening of the sickle cell trait could reduce the frequency of wrong genotype assignment.

Received 12/12/2018

Review began 12/18/2018

Review ended 12/29/2018

Published 12/31/2018

๑) Copyright 2018

Aderotoye-Oni et al. This is an open

access article distributed under the terms

of the Creative Commons Attribution

License CC-BY 3.0., which permits

unrestricted use, distribution, and

reproduction in any medium, provided the original author and source are credited.
Categories: Internal Medicine, Preventive Medicine, Public Health

Keywords: sickle cell disease, anemia, public awareness, public health analysis, caregiver burden

\section{Introduction}

Sickle cell disease (SCD) is a global health problem affecting over 100 million people [1-2] and is most common in people of African descent. Every year, 300,000 babies of all races are born with sickle cell disease globally; half of those cases are in Nigeria [3]. Despite SCD being a predominant public health concern in Nigeria, the literature remains scarce and not uniformly available with regards to the exact mortality rates in Nigeria. Estimates suggest that $50 \%-80 \%$ of these patients will die before adulthood [4]. It has been estimated that about $2.3 \%$ of the Nigerian population suffer from the disorder and over 40 million Nigerians are carriers of the sickle cell gene, making it the most common inherited genetic disorder affecting Nigerians and, thus, a significant community health concern [5]. Every single day, Nigeria loses about 2,300 under five-year-olds and the under-five mortality rate stands at 104 per 1000 live births in 2016 [6].

SCD is an autosomal recessive disorder and can be clinically expressed either by receiving two copies of hemoglobin ( $\mathrm{Hb}) \mathrm{S}$ (sickle cell anemia) or one copy of $\mathrm{HbS}$ plus another $\beta$-globin variant (such as $\mathrm{HbC}, \beta$ thalassemia, $\mathrm{HbD}$, or $\mathrm{HbE}$ ) [7]. Unlike the normal bi-concave disc shape of a red blood cell (RBC), the mutation of the $\beta$-globin gene results in the abnormal development of RBCs, causing them to become stiff, sticky, and sickle-shaped when deoxygenation prevails. Consequently, this affects the oxygen-carrying capacity of the cells and their ability to pass through vessels easily [8].

The presence of the HbS gene can be detected either prenatally or postnatally [3,9]. Prenatally, diagnosis can be made via chorionic villus sampling and amniocentesis; postnatally, the sickling test (determines carrier status), Hb electrophoresis, high-performance liquid chromatography (HPLC), isoelectric focusing (IEF), and DNA analysis can be used to diagnose SCD. 
SCD interferes with many aspects of the patients' and their family members' lives, including psychosocial development, education, marital condition, employment, and overall quality of life [10]. Genetic screening and counseling help ensure that parents make informed decisions regarding family planning and reproduction and have the opportunity to provide early preventive interventions to children with SCD.

The most common technique used to diagnose SCD and to identify sickle cell trait carriers is $\mathrm{Hb}$ electrophoresis [11]. In general, adults may have the following types of $\mathrm{Hb}: \mathrm{HbA} 95 \%$ to $98 \%, \mathrm{HbA}_{2} 2 \%$ to $3 \%$, $\mathrm{HbF} 0.8 \%$ to $2 \%$, $\mathrm{HbS} 0 \%$, and $\mathrm{HbC} 0 \%$. For infants and children, the Hb consists of the following types: $\mathrm{HbF}$ (newborn) $50 \%$ to $80 \%, \mathrm{HbF}$ (six months) $8 \%$, and $\mathrm{HbF}$ (over six months) $1 \%$ to $2 \%$. Abnormal laboratory results signify the presence of possibly significant levels of abnormal $\mathrm{HbS}$, which may indicate SCD and other hemoglobinopathies [12-13].

The average age at which the confirmation of the Hb genotype in children with SCD in Lagos, Nigeria, occurs is around 27.33 months. There are several essential implications associated with knowing one's sickle cell trait status, ranging from ethical considerations (in vitro and in vivo genetic testing) to those concerning societal prejudices [14]. Due to a lack of prenatal diagnosis, three-quarters of the children with SCD are at risk of premature death due to delayed medical intervention [15-16].

The aim of our study was to determine the prevalence and correlation of missed sickle cell disease carrier identification among parents of children with SCD.

\section{Materials And Methods \\ Study design}

A prospective, one-center, cross-sectional study was performed at a pediatric sickle cell clinic. The clinic was in a tertiary health institution and is one of the main referral facilities providing both general and specialist pediatric care for inhabitants of one of the largest cities in West Africa. Our study was conducted over three months from January 2014 to March 2014. A semi-structured questionnaire, developed by the study team, was administered to 133 parents of children registered at the pediatric sickle cell clinic who were enrolled in the study.

Data regarding parents' age, level of education, family size, whether the parent's genotype was known before the birth of their child with SCD, and the effect of having a child with SCD on various aspects of daily life, including finances, education, and family interaction, was collected. The biological parent(s) of the child(ren) presenting at the sickle cell clinic and those who have or had a child with SCD who is or was tested and registered at the sickle cell clinic were included in the study. The parents of the child(ren) with SCD presenting with life-threatening medical emergencies were excluded. During the appointments at the sickle cell clinic, the parents were explained the study and consent was taken.

\section{Sample size calculation}

$\mathrm{N}=\mathrm{Z}^{2} \mathrm{p}(1-\mathrm{p}) / \mathrm{d}^{2}$, where "N" is the minimum sample size, " $\mathrm{Z}$ " is the critical value in the two-tailed test, " $p$ " is the expected proportion of wrong carrier statuses in the population, and " $\mathrm{d}$ " is the permissible standard error. Here, $\mathrm{Z}=1.96, \mathrm{p}=8 \%$ and $\mathrm{d}=0.05$. Therefore, $\mathrm{N}=1.962 \times 0.08(0.092) / 0.0025=113.096$. If $10 \%$ is added for attrition, sample size becomes 124 patients. One hundred and thirty parents of children with SCD were studied. The calculations were based on a brief pilot study conducted by the authors at the same site.

\section{Statistical methods}

Continuous variables were reported as mean (standard deviation) and range and categorical variables as number (percent). The Chi-square test was used to analyze between-group differences for the categorical variables. A p-value of $<0.05$ was considered statistically significant. All the analyses were done using SAS 9.4 (SAS Institute, Cary, NC, US).

\section{Results}

\section{Age, sex, religion, and marital status of parents of children with SCD}

A total of 133 parents of children with SCD were assessed during the study period. They consisted of 125 mothers (96\%) and eight fathers (4\%). The ages of the parents ranged from 23 to 55 years with a mean of 37.3 years. Ninety (67.7\%) of the parents were Christian, and 43 (32.3\%) were Muslim. None of the parents reported traditional practices as a religion. A majority of the parents interviewed were married (93.23\%), three were widowed (2.3\%), and two were single (1.5\%).

\section{Level of education and monthly income of the parents}

A total of 52 parents (39.1\%) had completed secondary education, 41 parents (30.8\%) received tertiary level education, 18 parents (13.5\%) had completed primary education, and 19 parents (14.3\%) had completed a level of education considered as other. The majority of the parents $(47,35.3 \%)$ reported a monthly income of 


\section{Cureus}

10-30,000 naira, 32 parents (24.1\%) reported 30-60,000 naira, 24 parents (18\%) reported 60-100,000 naira, 16 parents (12\%) reported more than 100,000 naira, and 14 parents (10.5\%) reported less than 10,000 naira (Tables 1-4). Conversion to US dollars has not been included in the tables due to the economic variability and constant fluctuations in market exchange rates. The financial impact would be inadequately gauged by conversion against US dollars.

\begin{tabular}{|c|c|c|c|c|c|c|c|}
\hline \multicolumn{8}{|c|}{ Respondents Initial Genotype } \\
\hline $\begin{array}{l}\text { Monthly } \\
\text { Income }\end{array}$ & \multicolumn{2}{|c|}{$\begin{array}{l}\text { Correct Freq. } \\
(\%)\end{array}$} & $\begin{array}{l}\text { Misidentified Public Freq. } \\
(\%)\end{array}$ & $\begin{array}{l}\text { Misidentified I } \\
\text { (\%) }\end{array}$ & Private Freq. & $\begin{array}{l}\text { Unknown Freq. } \\
\text { (\%) }\end{array}$ & Total \\
\hline$<10 \mathrm{k}$ naira & \multicolumn{2}{|c|}{$3(4.76 \%)$} & $0(0 \%)$ & $1(6.67 \%)$ & & $10(19.23 \%)$ & 14 (10.53\%) \\
\hline 10-30k naira & \multicolumn{2}{|c|}{17 (26.98\%) } & $0(0 \%)$ & 5 (33.33\%) & & $25(48.08 \%)$ & 47 (35.34\%) \\
\hline 30-60k naira & \multicolumn{2}{|c|}{$16(25.40 \%)$} & $2(66.67 \%)$ & $3(20 \%)$ & & $11(21.15 \%)$ & 32 (24.06\%) \\
\hline 60-100k naira & \multicolumn{2}{|c|}{15 (23.81\%) } & $1(33.33 \%)$ & $2(13.33 \%)$ & & $6(11.54 \%)$ & 24 (18.05\%) \\
\hline$>100 \mathrm{k}$ naira & \multicolumn{2}{|c|}{$12(19.05 \%)$} & $0(0 \%)$ & $4(26.67 \%)$ & & $0(0 \%)$ & 16 (12.03\%) \\
\hline Total & \multicolumn{2}{|c|}{$63(47.37 \%)$} & $3(2.26 \%)$ & $15(11.28 \%)$ & & $52(39.10 \%)$ & $133(100 \%)$ \\
\hline \multicolumn{8}{|c|}{ Chi-Square Tests } \\
\hline & & \multicolumn{2}{|c|}{ Value } & & df & & Asymp Sig. (2-sided) \\
\hline \multicolumn{2}{|c|}{ Pearson Chi-Square } & \multicolumn{2}{|c|}{28.384 (a) } & & 12 & \multicolumn{2}{|l|}{.005} \\
\hline \multicolumn{2}{|c|}{ Likelihood Ratio } & \multicolumn{2}{|c|}{34.246} & & 12 & \multicolumn{2}{|l|}{.001} \\
\hline \multicolumn{2}{|c|}{ No of Valid Cases } & \multicolumn{2}{|l|}{133} & & & & \\
\hline
\end{tabular}

\section{TABLE 1: Variation with monthly income (respondents)}




\section{Cureus}

\begin{tabular}{|c|c|c|c|c|c|}
\hline \multicolumn{6}{|c|}{ Spouse Initial Genotype } \\
\hline Monthly Income & $\begin{array}{l}\text { Correct Freq. } \\
(\%)\end{array}$ & $\begin{array}{l}\text { Misidentified Public Freq. } \\
\text { (\%) }\end{array}$ & $\begin{array}{l}\text { Misidentified Private Freq. } \\
(\%)\end{array}$ & $\begin{array}{l}\text { Unknown Freq. } \\
\text { (\%) }\end{array}$ & Total \\
\hline <10k naira & $1(3.22 \%)$ & $0(0 \%)$ & $2(6.67 \%)$ & 11 (15.94\%) & $\begin{array}{l}14 \\
(10.53 \%)\end{array}$ \\
\hline 10-30k naira & $8(25.51 \%)$ & $1(33.33 \%)$ & $6(20 \%)$ & 32 (46.38\%) & $\begin{array}{l}47 \\
(35.34 \%)\end{array}$ \\
\hline 30-60k naira & $9(29.03 \%)$ & $0(0 \%)$ & $8(26.67 \%)$ & 15 (21.74\%) & $\begin{array}{l}32 \\
(24.06 \%)\end{array}$ \\
\hline 60k-100k naira & 7 (22.58\%) & $0(0 \%)$ & $8(26.67 \%)$ & 9 (13.04\%) & $\begin{array}{l}24 \\
(18.04 \%)\end{array}$ \\
\hline >100k naira & 6 (19.35\%) & $2(66.67 \%)$ & $6(20 \%)$ & $2(2.90 \%)$ & $\begin{array}{l}16 \\
(12.03 \%)\end{array}$ \\
\hline Total & $31(23.31 \%)$ & $3(2.26 \%)$ & $30(22.56 \%)$ & $69(51.88 \%)$ & $133(100 \%)$ \\
\hline \multicolumn{6}{|l|}{ Chi-Square Tests } \\
\hline & Value & df & \multicolumn{3}{|l|}{ Asymp. Sig. (2- sided) } \\
\hline $\begin{array}{l}\text { Pearson Chi- } \\
\text { Square }\end{array}$ & 28.969 & 12 & \multicolumn{3}{|l|}{.004} \\
\hline Likelihood Ratio & 28.851 & 12 & \multicolumn{3}{|l|}{.004} \\
\hline No of Valid Cases & 133 & & & & \\
\hline
\end{tabular}

TABLE 2: Variation with monthly income (spouse) 


\section{Cureus}

Respondents Initial Genotype

\begin{tabular}{|c|c|c|c|c|c|}
\hline $\begin{array}{l}\text { Educational } \\
\text { Level }\end{array}$ & $\begin{array}{l}\text { Correct Freq. } \\
(\%)\end{array}$ & $\begin{array}{l}\text { Misidentified Public Freq. } \\
(\%)\end{array}$ & $\begin{array}{l}\text { Misidentified Private Freq. } \\
\text { (\%) }\end{array}$ & $\begin{array}{l}\text { Unknown Freq. } \\
(\%)\end{array}$ & Total \\
\hline None & $0(0 \%)$ & $0(0 \%)$ & $0(0 \%)$ & $3(5.8 \%)$ & $3(2.3 \%)$ \\
\hline Primary & 5 (7.9\%) & 1 (33.3\%) & 1 (6.7\%) & $11(21.2 \%)$ & 18 (13.5\%) \\
\hline Secondary & $18(28.6 \%)$ & $0(0 \%)$ & $4(26.7 \%)$ & $30(57.7 \%)$ & 52 (39.1\%) \\
\hline Tertiary & 28 (44.4\%) & 2 (66.7\%) & $6(40 \%)$ & 5 (9.6\%) & 41 (30.8\%) \\
\hline Other & $12(19 \%)$ & $0(0 \%)$ & $4(26.7 \%)$ & 3 (5.8\%) & 19 (14.3\%) \\
\hline Total & 63 (47.4\%) & $3(2.3 \%)$ & 15 (11.3\%) & 52 (39.1\%) & 133 (100\%) \\
\hline
\end{tabular}

Chi-Square Tests

\begin{tabular}{llcc|} 
& Value & df & Asymp Sig. (2-sided) \\
Pearson Chi-Square & 36.621 (a) & 12 & 12 \\
Likelihood Ratio & 41.006 & & .000 \\
No of Valid Cases & 133 & & .000 \\
\hline
\end{tabular}

\section{TABLE 3: Variation with education (respondents)}

(a) 11 cells $(55.0 \%)$ have expected count less than 5 . The minimum expected count is .07 .

Primary: First seven to nine years of formal education

Secondary: Last four years of formal education

Tertiary: College and graduate schools

Other: Certificate programs after secondary school 


\section{Cureus}

Spouse Initial Genotype

$\begin{array}{llllll}\begin{array}{l}\text { Educational } \\ \text { Level }\end{array} & \begin{array}{l}\text { Correct Freq. } \\ (\%)\end{array} & \begin{array}{l}\text { Misidentified Public Freq. } \\ (\%)\end{array} & \begin{array}{l}\text { Misidentified Private Freq. } \\ (\%)\end{array} & \begin{array}{l}\text { Unknown Freq. } \\ (\%)\end{array} & \begin{array}{l}\text { Total } \\ \text { None }\end{array} \\ \begin{array}{l}0(0 \%) \\ \text { Primary }\end{array} & 3(9.7 \%) & 0(0 \%) & 0(0 \%) & 3(4.3 \%) & 3(0.3 \%) \\ \text { Secondary } & 9(29 \%) & 2(66.7 \%) & 1(3.3 \%) & 14(20.03 \%) & 18(13.5 \%) \\ \text { Tertiary } & 15(48.4 \%) & 1(33.33 \%) & 7(23.3 \%) & 34(49.3 \%) & 52(39 \%) \\ \text { Other } & 4(12.9 \%) & 0(0 \%) & 16(53.3 \%) & 9(13 \%) & 41(30.8 \%) \\ \text { Total } & 31(23.3 \%) & 3(2.3 \%) & 6(20 \%) & 9(13 \%) & 19(14.3 \%)\end{array}$

Chi-Square Tests

\begin{tabular}{llll} 
& Value & $\mathrm{df}$ & Asymp Sig. (2-sided) \\
Pearson Chi-Square & 29.630 (a) & 12 & .003 \\
Likelihood Ratio & 33.070 & 12 & .001 \\
No of Valid Cases & 133 & & \\
\hline
\end{tabular}

TABLE 4: Variation with education (spouse)

(a) 12 cells $(60.0 \%)$ have expected count less than 5 . The minimum expected count is .07 .

\section{When and where parent first learned about SCD}

The parents who knew about SCD before the birth of their child with SCD $(67,50.4 \%)$ was almost evenly split with those parents who learned about SCD after the birth of a child with SCD (66, 49.6\%). A majority of the parents $(79,50.6 \%)$ learned about SCD via the hospital, 27 parents (17.3\%) learned about SCD via school, 26 parents (16.7\%) learned via friends, neighbors, etc., 11 parents (7.1\%) learned from family, 11 parents (7.1\%) learned from media, and two parents (1.2\%) learned about SCD from church SCD campaigns.

\section{Reason parents got their initial genotype tested}

Twenty-three parents (33.8\%) initially did their genotyping due to school requirements, 14 (20.6\%) due to an awareness of the disease, 13 (19.1\%) due to premarital counseling, 10 (14.7\%) as part of their antenatal care (ANC), four (5.9\%) due to a family history of SCD, and four (5.9\%) because of church/mosque SCD campaigns.

\section{Currently reported genotype of the respondent parent}

All 133 respondents reported a current genotype of sickle cell trait (AS) (100\%), with 70 (52.6\%) tested in a private lab while $63(47.4 \%)$ were tested in a public lab.

\section{Currently reported genotype of the second parent}

The respondents also reported on their spouse's/second-parent genotype status. The majority (130, 97.7\%) were reported to be $\mathrm{AS}$, one parent $\mathrm{HbC}$ trait $\mathrm{AC})(0.75 \%)$, one parent sickle cell $\mathrm{HbC}$ disease (SC) $(0.75 \%)$, and one parent sickle cell anemia (SS) (0.75\%). Sixty-nine of those (51.9\%) were reported to have done their genotype in a private lab while 64 parents $(48.1 \%)$ reported having completed their genotype in a public lab.

\section{Genotype initially assigned to respondent}

A total of 63 respondents (47.4\%) reported to have known their correct genotype, 18 respondents (13.5\%) reported to have been misidentified as normal $\mathrm{Hb}(\mathrm{AA})$; of those, three respondents $(2.3 \%)$ had their genotype done in a public lab, and 15 respondents (11.3\%) had their genotype done in a private lab. A total of 69 respondents (51.9\%) genotypes were unknown before the marriage or conception of their child with SCD.

\section{Genotype initially assigned to the second parent}

A total of 31 spouses/second parents (23.3\%) were reported to have known their correct genotype initially; 


\section{Cureus}

33 parents (24.8\%) were misidentified as AA; of those, three parents (2.3\%) carried out the genotype in a public lab while 30 parents (22.6\%) conducted their exam in a private lab. Over half of the spouses/second parents (69 parents, 51.9\%) were reported not to have known their genotype before marriage or conception of their child with SCD (refer to Table 5 for the combined figures of respondents and second parent). The total $\mathrm{n}=266$ is a reflection of the total amount of parents. Though only one parent completed the questionnaire, information like their genotype for their spouse could be counted, thus, a total of 266 rather than 133 in Table 5.

\begin{tabular}{|c|c|c|c|}
\hline & \multicolumn{2}{|l|}{ Responses } & \\
\hline & $\mathrm{N}$ & Percent & \\
\hline Correctly identified & 94 & 35.3 & \\
\hline Misidentified as AA (Pub) & 6 & 2.3 & \multirow{2}{*}{19.2} \\
\hline Misidentified as AA (Priv) & 45 & 16.9 & \\
\hline Unknown & 121 & 45.5 & \\
\hline Total & 266 & 100 & \\
\hline
\end{tabular}

TABLE 5: Initially assigned genotype (respondent $(\mathrm{N}=133)+$ spouse $(\mathrm{N}=133))$

Total percent of misidentified genotypes is $19.2 \%$.

\section{Consideration of genotype before marriage or conception}

The majority of the respondents $(95,71.4 \%)$ reported that they did not consider their genotype nor their partners' before entering into marriage or conceiving their child with SCD while 38 did (Table 6).

\begin{tabular}{|c|c|c|c|c|c|}
\hline \multirow{2}{*}{\multicolumn{2}{|c|}{$\begin{array}{l}\text { Genotypes taken into consideration before } \\
\text { marriage/conception }\end{array}$}} & \multicolumn{4}{|c|}{ Initial Genotype (Respondents + Spouse) } \\
\hline & & $\begin{array}{l}\text { Correct Freq. } \\
(\%)\end{array}$ & $\begin{array}{l}\text { Misidentified Freq. } \\
\text { (\%) }\end{array}$ & $\begin{array}{l}\text { Unknown Freq. } \\
\text { (\%) }\end{array}$ & Total \\
\hline \multicolumn{2}{|l|}{ Yes } & $10(32.3 \%)$ & $24(72.7 \%)$ & $4(5.8 \%)$ & $38(28.6 \%)$ \\
\hline \multicolumn{2}{|l|}{ No } & $21(67.7 \%)$ & $9(27.3 \%)$ & $65(94.2 \%)$ & $95(71.4 \%)$ \\
\hline \multicolumn{2}{|l|}{ Total } & $31(23.3 \%)$ & $33(24.8 \%)$ & $69(51.9 \%)$ & $\begin{array}{l}133 \\
(100.0 \%)\end{array}$ \\
\hline \multicolumn{6}{|l|}{ Chi-Square Tests } \\
\hline & Value & df & \multicolumn{3}{|l|}{ Asymp. Sig. (2-sided) } \\
\hline Pearson Chi-Square & 49.270 (a) & 2 & \multicolumn{3}{|l|}{.000} \\
\hline Likelihood Ratio & 50.935 & 2 & \multicolumn{3}{|l|}{.000} \\
\hline No of Valid Cases & & 133 & & & \\
\hline
\end{tabular}

\section{TABLE 6: Genotypes taken into consideration before marriage/conception}

(a) 0 cells $(0 \%)$ have expected count less than 5 . The minimum expected count is 8.86 .

\section{Genetic counseling}

The majority of parents $(117,88 \%)$ reportedly received genetic counseling after discovering their child had SCD while 16 (12\%) did not (Table 7). 


\section{Cureus}

\begin{tabular}{|c|c|c|c|c|c|}
\hline & & \multicolumn{4}{|c|}{ Initial Genotype (Respondent + Spouse) } \\
\hline & & Correct Freq. (\%) & Misidentified Freq. (\%) & Unknown Freq. (\%) & Total \\
\hline \multirow{2}{*}{ Genetic Counseling } & No & $3(9.7 \%)$ & $6(18.2 \%)$ & $7(10.1 \%)$ & $16(12.0 \%)$ \\
\hline & Yes & $28(90.3 \%)$ & $27(81.8 \%)$ & $62(89.9 \%)$ & $117(88.0 \%)$ \\
\hline Total & & $31(23.3 \%)$ & $33(24.8 \%)$ & $69(51.9 \%)$ & $133(100.0 \%)$ \\
\hline \multicolumn{6}{|l|}{ Chi-Square Tests } \\
\hline & Value & df & Asymp. Sig. (2-sided) & & \\
\hline Pearson Chi-Square & 1.574(a) & 2 & .455 & & \\
\hline Likelihood Ratio & 1.457 & 2 & .483 & & \\
\hline No of Valid Cases & & 133 & & & \\
\hline
\end{tabular}

\section{TABLE 7: Genetic counseling}

(a) Two cells (33.3\%) have expected count less than 5 . The minimum expected count is 3.73 .

\section{Discussion}

The findings show that the prevalence of a surprise diagnosis of SCD in children of unsuspecting and illprepared parents is high (52\%). Parents and caregivers of children with SCD are faced with several challenges, which can be costly for the family and can result in a subpar health-related quality of life due to the parents' ill-preparedness to finance a child's healthcare [17].

Early diagnosis of SCD provides the opportunity to deliver early treatment and appropriate and timely vaccination and management [18]. A randomized controlled trial comparing early penicillin prophylaxis to the placebo was terminated eight months early due to the overwhelming evidence in support of the ability of penicillin to prevent pneumococcal sepsis in babies with SCD, with an $84 \%$ reduction in the rate of infection and the absence of fatalities in the penicillin prophylaxis study group [16]. The overall health of infants with SCD depends on the psychosocial preparedness of the parents [19].

Missed identification poses a significant impact on the type of care received. Several interventions introduced in early childhood, including penicillin prophylaxis, transcranial Doppler scans, and pneumococcal vaccination, have decreased the mortality rate [20]. The improved quality of life with the early introduction of analgesics, high fluid intake, folic acid supplementation, antibiotics, rest, and good nutrition is necessary to provide the best prospect for the child with SCD [21].

SCD has a considerable influence on the socioeconomic status of a family. Twenty-two percent of respondents reported having marital discord due to the stress of having a child with SCD; marital discord can further negatively influence the quality of care of their child with SCD due to potentially creating stressors at home for the child with SCD. Parents also reported a high incidence of their other children showing resentment towards their child(ren) with SCD (19\%), again potentially increasing the stressors the child with SCD has to deal with it. Nevertheless, many parents also reported that having a child with SCD has brought the family closer together (47\%), thus demonstrating that families can rally together to serve as a support system for one another. Respondents also frequently reported the frequent absences their child with SCD had from school. However, parents did not let it affect the school attendance of their other children (78.2\%).

As mentioned earlier, SCD can have a significant impact on the finances of a household. Most of the parents reported a monthly household income of 10-30,000 naira. Though a majority of the respondents stated that they spend less than 2,000 naira/month for the general care of one child with SCD, financial hardship can easily arise when the child falls ill or needs to be hospitalized. According to respondents, most hospitalizations of a child with SCD cost more than 20,000 naira (60\%), thus a large majority of the respondents of this study spend a range, from $60 \%$ of their monthly income to all of their income, with the need to also take out loans (43\%) per hospitalization. Financial problems are compounded because many parents also have unstable employment. Though a majority of respondents reported that there was no influence on their employment due to having a child with SCD, $14.5 \%$ of respondents stated that they were voluntarily unemployed to care for a child with SCD, further reducing the income the household earns/month. 
The study demonstrated that knowledge of SCD correlates with educational level and financial status. Moreeducated parents knew about SCD before having an affected child. The highest risk of being misidentified as a non-carrier of a hemoglobinopathy trait lies with those in a higher income bracket (> 60,000 Naira) and those with higher levels of formal education. Respondents in these classifications were less likely to have initially unknown genotypes and had an increased likelihood of using a private lab facility. Utilization of private lab facilities proves to be a precarious option due to the lack of oversight and quality control, which may contribute to the significantly higher rate of misidentification of genotypes (88\%) as compared to those that occur in public facilities (12\%). Inversely, it can be inferred that the lack of education and funds inadvertently protected from incorrect identification. However, the same group is shown to be at an increased risk due to ignorance and lack of preparation.

The majority of respondents who knew about SCD before the birth of their child with the disorder reported learning about the health condition through the hospital (50\%), followed by school (17\%). Surprisingly, media (TV, newspaper, radio, etc.) was the second least cited source of knowledge about the disorder (7\%). Most respondents stated that school (34\%) was the reason for their initial (before having a child with SCD) genotype testing, followed by awareness of the disorder (20\%) and marital counseling (19\%). This demonstrates the significant public health role that hospitals and school systems play in educating and mobilizing the public about the disorder. It is also important to note that many respondents quoted "antenatal care" (14.7\%) as a reason for getting initial SCD genotyping done. This finding is significant, potentially correlating to the reason why more mothers than fathers are genotyped before having an affected child, also capturing another prospective technique to educate the population further.

\section{Limitations}

One of the limitations of the study was the inability or lack of access to interview both parents of each child, which resulted in questionable data regarding the income reported by the mother. Of the parents interviewed, mothers were the majority in the study; as a result, there is a biased motherly view of the data collected. Also, the educational status of the spouse was unable to be assessed, which inhibited the ability to categorize the social class of each participant. Another limitation of the study was the "Nigerian parlance," encountered while administering the questionnaire. Due to cultural reasons, many parents would not want to speak negatively, as they do not want their statements to come to fruition as a result. Instead of answering questions truthfully, or candidly, parents would give answers such as "God will provide," "It is well," “The child is strong," and "God forbid." This occurrence slightly disturbed the data collection during the study.

\section{Recommendations}

The government should initiate an SCD awareness campaign, utilizing more media sources to reach the population, creating awareness and providing knowledge of SCD. A push to have schools and antenatal care providers strengthen SCD awareness and educative programs would also be a great benefit to society. Lastly and most importantly, the government should help standardize and improve the quality control of laboratory practices, especially in the private sector, by implementing policies and establishing oversight over the industry. This project would serve as a great pilot for a multicenter study to increase the power and reduce variance.

\section{Conclusions}

SCD presents significant challenges to both the families of affected children and the country's healthcare system. There is a high rate of missed information and misinformation about the risk of having children with SCD, leaving parents ill- or unprepared. Currently, private hospitals are less accurate at identifying hemoglobin genes relevant to SCD. Additionally, antenatal care and schools are great platforms to promote the testing and awareness of the disease. This study is the first to address the issue of missed identification and incorrect identification of sickle cell trait carriers in Nigeria. Our results demonstrate that there is room for cost-effective, public-health-oriented contributions to increase the awareness and implementation of screening for SCD. Furthermore, a greater push in ensuring that citizens receive accurate and affordable SCD genotyping results by establishing quality control standards. These measures can help combat the prevalence of the disease and empower potential future families to make informed decisions.

\section{Appendices}

Figures 1-3 show the semi-structured questionnaire created and used by the authors for the study: 


\section{Cureus}

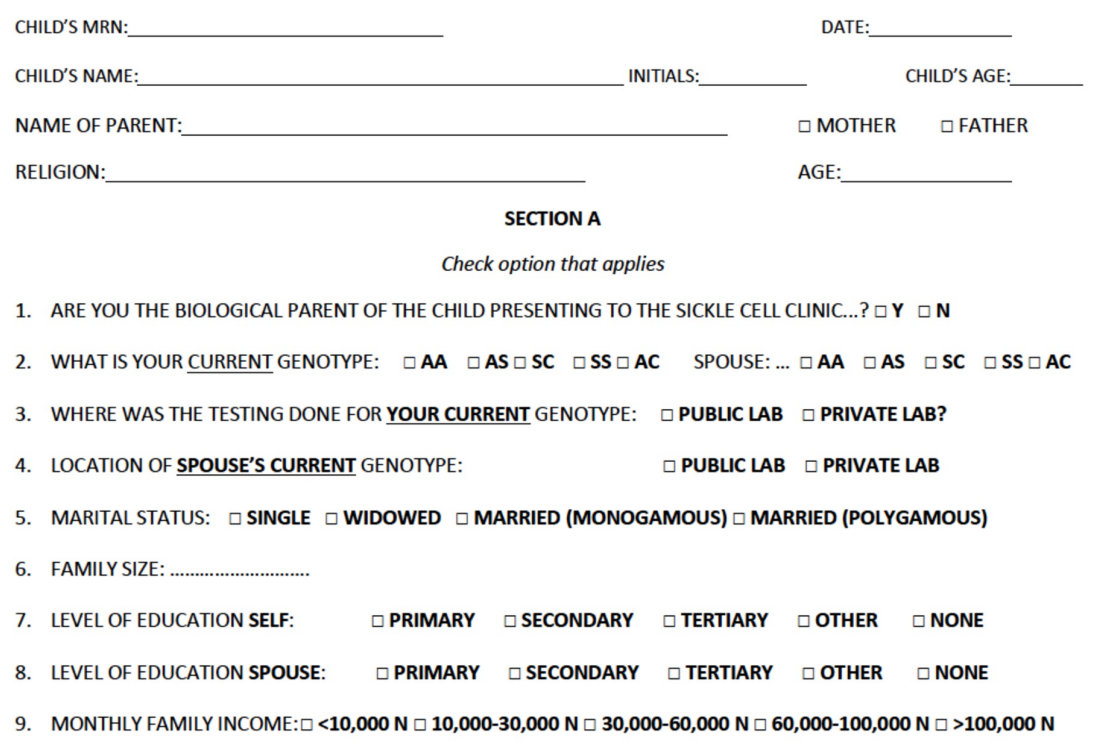

SECTION B

1. HOW MANY CHILDREN DO YOU CURRENTLY HAVE WITH SCD?

2. HAVE YOU EVER LOST ANY CHILD(REN) TO SCD? ?

3. IS/ARE THE CHILD(REN) OUT OF WEDLOCK: $\square$ YES $\square$ NO

4. WHEN DID YOU FIND OUT ABOUT SCD?

$\square$ BEFORE YOU HAD A CHILD WITH SCD $\quad$ AFTER YOU HAD A CHILD WITH SCD

5. DID YOU RECEIVE GENETIC COUNSELING AFTER HAVING YOUR FIRST CHILD WITH SCD? $\quad \square$ YES $\square$ NO

6. HOW DID YOU LEARN ABOUT SCD: (check all that apply) ...? $\square$ HOSPITAL/SCD CLINIC $\square$ SCHOOL $\square$ MEDIA (TV, RADIO, NEWSPAPER...) $\square$ FAMILY $\square$ FRIENDS, NEIGHBORS, etc. $\square$ OTHER..

\section{SECTION C}

1. YOUR SPOUSE'S GENOTYPE BEFORE YOU HAD A CHILD(REN) WITH SCD WAS: $\square$ CORRECT GENOTYPE- LOCATION OF EXAM DONE AT A: $\square$ PUBLIC LAB $\square$ PRIVATE LAB $\square$ INCORRECT GENOTYPE- LOCATION OF EXAM DONE AT A: $\square$ PUBLIC LAB $\square$ PRIVATE LAB

FIGURE 1: SCD questionnaire: page 1 


\section{Cureus}

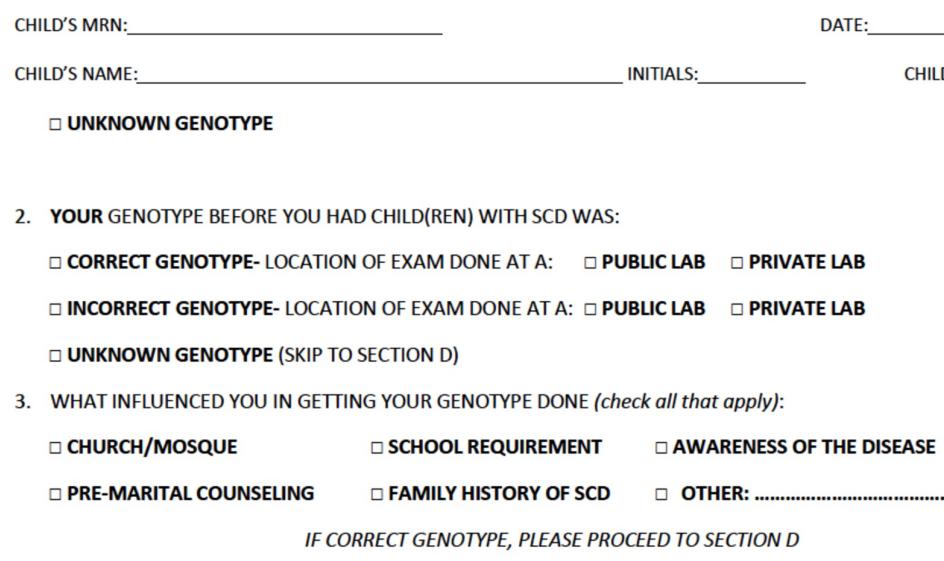

WHAT INFLUENCE HAS HAVING A CHILD WITH SCD HAD ON THE FOLLOWING ASPECTS OF LIFE. PLEASE CHOOSE ALL THAT APPLY:

\section{A. FINANCE}

$\square$ NO influence on financial matter of the family

$\square$ Difficulty paying HOUSE RENT or SCHOOL FEES

$\square$ LOSS of income 口Other:

$\square$ LOANS have been taken out

1. HOW MUCH DOES YOUR FAMILY USUALLY SPEND IN A MONTH TO CARE FOR ONE CHILD WITH SCD: NAIRA

2. ON AVERAGE HOW MANY TIMES IS YOUR CHILD WITH SCD HOSPITALIZED A YEAR? DAYS

3. WHEN YOUR CHILD WITH SCD IS HOSPITALIZED WHAT IS THE AVERAGE COST SPENT DURING HOSPITALIZATION: NAIRA

B. EMPLOYMENT

$\square$ NO influence on employment

$\square$ Involuntary unemployment

$\square$ Necessary voluntary unemployment of one parent 口QUERY at work

$\square$ Frequent job terminations

$\square$ Other:

$\square$ Self-employed, frequent closing of shop or inability to trade

FIGURE 2: SCD questionnaire: page 2 
CHILD'S MRN:

CHILD'S NAME:

DATE:

CHILD'S AGE:

C. EDUCATION

\author{
$\square$ NO influence on your child with SCD education \\ $\square$ FREQUENT Absences \\ $\square$ N/A child too young for school
}

$\square$ COURSE failures

$\square$ REPEATED grade levels

$\square$ Other...

1. HOW MANY DAYS DOES YOUR CHILD MISS IN A SCHOOL TERM DUE TO SCD: ...
$\square \leq 2$ DAYS
口 3-6 DAYS
$\square$ 1-2 WEEKS
$\square$ 3-4 WEEKS
$\square>1$ MONTH $\square$ N/A

2. DOES ANY OF THE SIBLINGS OF THE CHILD WITH SCD MISS SCHOOL?... $\square$ YES $\square$ NO $\square N / A$

D. FAMILY

$\square$ NO influence on family dynamics

$\square$ Siblings show resentment towards child with SCD

$\square$ Having a child with SCD has brought the family closer $\square$ Other children needs have been neglected

$\square$ Day-to-day interactions within family are disrupted

$\square$ Other:

E. MARRIAGE

$\square$ NO influence on your marriage

$\square$ Marital discord, but marriage remains intact

$\square$ Made marriage stronger $\square$ Marital separation

$\square$ Divorce

$\square$ Other: .

\section{FIGURE 3: SCD questionnaire: page 3}

SCD: sickle cell disease

\section{Additional Information \\ Disclosures}

Human subjects: Consent was obtained by all participants in this study. Lagos State University Teaching Hospital issued approval LREC/10/06/389. The research was granted full approval by the Health Research and Ethics Committee of Lagos State University Teaching Hospital. Date of Approval: 11/03/2014 Reference Number: LREC/10/06/389. Animal subjects: All authors have confirmed that this study did not involve animal subjects or tissue. Conflicts of interest: In compliance with the ICMJE uniform disclosure form, all authors declare the following: Payment/services info: The research project was carried out under the The Fulbright U.S. Student Program. The program provides grants for individually designed study/research projects after a grant has been accepted. The program helps deepen ties within the higher education communities in the United States and abroad via research projects and immersion into various countries' culture. . Financial relationships: All authors have declared that they have no financial relationships at present or within the previous three years with any organizations that might have an interest in the submitted work. Other relationships: All authors have declared that there are no other relationships or activities that could appear to have influenced the submitted work.

\section{Acknowledgements}

I am thankful to the Fulbright Scholarship Program for providing me with this great opportunity to carry out this research project. I am beholden to Lagos State Teaching Hospital for opening up their institution to me to carry out my project. Lastly, I am grateful to those who assisted me during the preparation and execution of the project and report.

\section{References}

1. Sickle cell trait. (2014). Accessed: January 17, 2014: http://www.hematology.org/Patients/Anemia/SickleCell-Trait.aspx.

2. Rees DC, Williams TN, Gladwin MT: Sickle-cell disease. Lancet. 2010, 376:2018-2031. 10.1016/S01406736(10)61029-X

3. What is sickle cell anemia?. (2012). Accessed: November 8, 2013: https://www.nhlbi.nih.gov/healthtopics/sickle-cell-disease.

4. Makani J, Cox SE, Soka D, et al.: Mortality in sickle cell anemia in Africa: a prospective cohort study in Tanzania. PLoS One. 2011, 6:e14699. 10.1371/journal.pone.0014699 
5. The national burden of sickle cell disorder and the way forward . (2010). Accessed: January 18, 2011: http://www.sicklecellfoundation.com/wp-content/uploads/2015/05/Nat-Burden-SCD.pdf.

6. Serjeant GR, Serjeant BE: Sickle Cell Disease, 3rd Edition. Oxford University Press, New York; 2001.

7. Muoghalu CO: Sickle cell disease child mortality - a silent epidemic in Nigeria: issues in political economy . Blood Res Transfus J. 2018, 2:1-3.

8. Ashley-Koch A, Yang Q, Olney RS: Sickle hemoglobin (Hb S) allele and sickle cell disease: a HuGE review . Am J Epidemiol. 2000, 151:839-845. 10.1093/oxfordjournals.aje.a010288

9. Wethers DL: Sickle cell disease in childhood: part I. Laboratory diagnosis, pathophysiology and health maintenance. Am Fam Physician. 2000, 62:1013-1020.

10. The socioeconomic and cultural impact of sickle cell disease in Nigeria . (2016). Accessed: December 19, 2018: https://scholarworks.waldenu.edu/cgi/viewcontent.cgi?article=3672 \&context=dissertations.

11. Naik RP, Haywood C: Sickle cell trait diagnosis: clinical and social implications . Hematology Am Soc Hematol Educ Program. 2015, 2015 No. 1:160-167. 10.1182/asheducation-2015.1.160

12. Bunn HF: Approach to the anemias. Goldman's Cecil Medicine. Goldman L, Schafer AI (ed): Elsevier/Saunders, Philadelphia; 2016. 25th edition:1059-1068.

13. Goljan EF: Red blood cell disorders. Rapid Review Pathology. Goljan EF (ed): Elsevier Saunders, Philadelphia; 2014. 4th edition:279-317.

14. Nietert PJ, Silverstein MD, Abboud MR: Sickle cell anaemia. Pharmacoeconomics. 2002, 20:357-366.

15. Akodu SO, Diaku-Akinwumi IN, Njokanma OF: Age at diagnosis of sickle cell anemia in Lagos, Nigeria . Mediterr J Hematol Infect Dis. 2013, 5:e201300. 10.4084/MJHID.2013.001

16. Gaston MH, Verter JI, Woods G, et al.: Prophylaxis with oral penicillin in children with sickle cell anemia. N Engl J Med. 1986, 314:1593-1599. 10.1056/NEJM198606193142501

17. Adegoke SA, Kuteyi EA: Psychosocial burden of sickle cell disease on the family, Nigeria . Afr J Prim Health Care Fam Med. 2012, 4:380-385. 10.4102/phcfm.v4i1.380

18. Serjeant GR: Treatment of sickle cell disease in early childhood in Jamaica . Am J Pediatr Hematol Oncol. 1985, 7:235-239.

19. Whitten CF, Fischhoff J: Psychosocial effects of sickle cell disease . Arch Intern Med. 1974, 133:681-689. 10.1001/archinte.1974.00320160175016

20. Yanni E, Grosse SD, Yang Q, Olney RS: Trends in pediatric sickle cell disease-related mortality in the United States, 1983-2002. J Pediatr. 2009, 154:541-545. 10.1016/j.jpeds.2008.09.052

21. Reid CD, Charace S, Lubin B: Child and adolescent health care maintenance. Management and Therapy of Sickle Cell Disease. Diane, Darby, PA; 1995. 5-12. 